\title{
Financialization of Enterprise Assets and R\&D Investment
}

\author{
$\mathrm{Xu} \mathrm{Yang}{ }^{1}$ \\ ${ }^{1}$ School of Economics and Management, Beijing Jiaotong University, BJTU, Beijing, China
}

\begin{abstract}
This paper selects the panel data of 260 listed companies in China's GEM from 2013 to 2017, and uses a fixed effect regression model to verify and analyze the overall impact of asset financialization of small and medium-sized entrepreneurial companies on $R \& D$ investment. The results show that the two are positively related overall. In addition, from the perspective of the shareholding structure, the threshold effect model is used to explore how the direction and extent of the effect of asset financialization on corporate R\&D investment dynamically change. It is concluded that these will have a nonlinear relationship with the change in the shareholding structure. Only by optimizing the shareholding structure and adjusting the shareholding ratios of major shareholders and management to an appropriate range can the optimal promotion effect of asset financialization on enterprise $R \& D$ investment be achieved, and the harmonious development of the relationship between finance and real economy can be promoted.
\end{abstract}

\section{Introduction}

The real economy is an economy that enriches the country and creates wealth. In the current critical period of my country's economic transformation, only through continuous innovation and core competitiveness can we better promote the development of the real economy. For enterprises, to improve their independent innovation capabilities, it is necessary to increase investment in R\&D and focus on breaking through key core technologies in order to seize the opportunities for future competition. Therefore, especially under the influence of the current international trade friction and epidemic situation, enterprises should increase their investment in research and development, improve the performance of scientific and technological innovation, and then enhance my country's independent scientific research innovation capability. At the same time, with the slowdown of my country's economic growth and the rapid development of the financial industry, more and more companies are actively participating in financial activities, investing industrial capital in the financial industry, buying financial products, investing in bonds, stocks and so on. Therefore, "integration of industry and finance" and "removal from reality to virtuality" are also the current development trends of many enterprises.

Will the financialization of company assets affect R\&D investment and thus the development of the real economy? Based on the above background analysis, this article will select panel data of non-financial and real estate listed companies on my country's Growth Enterprise Market from 2013 to 2017 to discuss the overall impact of the company's asset financialization on R\&D investment. In the process of the impact of the company's asset financialization on R\&D investment, it will be affected by objective factors such as the shareholding structure. Therefore, when the shareholding structure presents different states, the relationship between the financialization of company assets and R\&D investment may change dynamically.

The contribution of this paper: (1) There is no unified conclusion on the impact of corporate asset financing on R\&D investment. Therefore, from the perspective of my country's national conditions, it is of practical significance to discuss the overall impact of asset financialization on the R\&D investment of small and medium-sized entrepreneurial enterprises, and to increase the level of innovation and development of enterprises. (2) From the perspective of qualitative and quantitative equity structure, discuss how management shareholding and equity concentration affect the dynamic change of the relationship between the two. This not only helps to enrich the research status of corporate asset financialization, but also helps companies to rationally arrange equity structure. It is of great practical significance for promoting the positive effect of corporate asset financialization on innovation investment.

\section{Theoretical analysis and research hypothesis}

Regarding the impact of the financialization of corporate assets on R\&D investment, there is currently no consensus at home and abroad. Gehringer found that non-financial enterprises increased their investment in financial assets for the purpose of preventing savings and easing corporate financing constraints[1]. The financialization of corporate assets can save financing costs and protect the source of funds for the future development of the enterprise[2]. At the same time, it can modify the financial statements of the 
enterprise and improve the financing ability of the entity[3][4]. In contrast, some scholars believe that entity companies invest more funds in the financial market, and speculative arbitrage motives are greater than prevention motives. According to the investment substitution theory, they will reduce the entity's physical operations and R\&D innovation activities[5].

For small and medium-sized entrepreneurial enterprises, due to the short establishment time and strong growth, for the steady and continuous development of the enterprise, the company has a strong demand for R\&D and innovation, but the cash flow is relatively unstable and continues to fluctuate. Therefore, enterprises' financial investment behavior is more likely to be based on motives for preventing savings and strategic development, by investing in financial assets, reducing operating risks, promoting continuous and stable operations, and avoiding future corporate shortages or even disruptions that affect R\&D investment[6]. Therefore, financial asset investment can reserve funds in advance for the company's future R\&D investment, broaden the financing channels, and play a role of capital buffer to ensure that the enterprise's scientific research projects can more conveniently use internal financing and reduce external financing costs, which can smoothly increase R\&D investment. Funding for innovation activities. Based on the above analysis, this article proposes Hypothesis 1:

H1: On the whole, the financialization of the assets of entrepreneurial companies will promote R\&D investment.

For small and medium-sized start-ups, when the shareholdings are too dispersed, the major shareholders cannot effectively and timely monitor the company's business decisions. According to the principal-agent theory, in order to pursue personal interests, managers make excessive financial investments out of profit-seeking motives and make behaviors that are not conducive to enterprise development. In the same way, when the control power of enterprises is highly concentrated, and there is a situation of dominance, the regulatory restraint mechanism of enterprises is virtually useless. At this time, the increased liquidity of the enterprise through financial investment is likely to be used for other aspects of the enterprise. The lack of rational and comprehensive analysis and judgment on the investment in R\&D projects has caused the enterprise to miss many valuable scientific research investment projects. In both cases, the financialization of corporate assets is not conducive to R\&D investment. Only when the shareholding ratio of large shareholders is relatively moderate for small and medium-sized enterprises, and equity is relatively balanced, at this time, the greater possibility for enterprises to allocate financial assets is to prevent savings and strategic motives, actively support R\&D activities, and ensure their capital investment. Therefore, in the process of increasing shareholding ratio of large shareholders, the relationship between asset financialization and R\&D investment is not static. Therefore, this article proposes the following hypothesis 2 :

$\mathrm{H} 2$ : The relationship between the financialization of corporate assets and R\&D investment will change dynamically as the concentration of equity increases. Only under a reasonable concentration of equity can the financialization of corporate assets promote the investment in R\&D.

Due to the short-sighted problems of entrusted agents and managers, and the different proportions of shares held by management, the motivation for the financialization of corporate assets is likely to change. When the percentage of shares held by the management is low, the management cannot converge with the interests of the shareholders due to the low percentage of shares held by the management. Similarly, if the equity held by the management is too high, the greater the control of the management, it will weaken other monitoring mechanisms to supervise the management. They may sacrifice the rights of other shareholders for the sake of maximizing their own interests and reduce the company's resource allocation. Efficiency, in both cases, the financialization of corporate assets is more likely to be for speculative gains, so investment in innovation activities will be crowded out accordingly. Therefore, the management's shareholding is too low or too high, and the financialization of corporate assets is not conducive to increasing the company's R\&D investment, but will play a reverse role. Only when the management's shareholding ratio is moderate, at this time, the management's shareholding achieves the equity incentive effect, effectively improves the principal-agent problem, and at the same time does not over-diversify the power, the external constraints are invalid, so that the financial investment income of the enterprise can effectively serve the innovation of the enterprise activity. Based on the above analysis, this paper proposes the following hypothesis 3:

H3: The relationship between the financialization of corporate assets and R\&D investment changes dynamically with the change in management's shareholding. Only under a reasonable management shareholding ratio, the financialization of corporate assets will promote R\&D investment.

\section{Research design}

\subsection{Sample selection and data source}

This article selects Chinese GEM non-financial listed companies as the research sample. In order to improve the usability of the data, the data was processed accordingly. In this paper, the panel data of 260 listed companies on the Growth Enterprise Market from 2013 to 2017 were finally selected, with a total of 1,300 effective data. The financial data of the sample companies are mainly obtained from the CSMAR database and the company's annual report, which are manually sorted and processed by $1 \%$ and $99 \%$ of the tailing through the stata software.

\subsection{Research variables}

For the definition of asset financialization, this paper mainly draws on the studies of Song Jun and Lu Yang and uses the proportion of financial assets in total assets to measure the degree of asset financialization[7], which is expressed in Fin. Considering that the research on investment in $R \& D$ activities in this paper is based on the 
micro level and the availability of data, therefore, drawing on the research results of Zhong Tianli[8], the R\&D expenditure of the company is used to measure the proportion of operating income to measure $R \& D$. The input intensity is expressed by RD. This article refers to the relevant literature on equity concentration and uses the first shareholder's shareholding ratio for measurement. This paper refers to the research literature of Liu Huafang and Yang Jianjun, and uses the ratio of the sum of shares held by management to the total share capital of the company for measurement. Refer to most domestic and foreign scholars' research on the relationship between the two, and control from company size (Size), profitability (Roa), financial risk (Lev), investment opportunity (Q), year (Year), industry (Ind), etc.

\subsection{Model design}

In order to verify Hypothesis 1, this paper proposes the following econometric model:

$$
\begin{aligned}
& \mathrm{Rd}_{i t}=\alpha_{1} \text { Fin }_{i t}+\alpha_{2} \text { Size }_{i t}+\alpha_{3} \text { Lev }_{i t}+\alpha_{4} Q_{i t} \\
& +\alpha_{5} \text { Roa }_{i t}+\alpha_{6} H_{i t}+\alpha_{7} \text { Manag }_{i t}+\varepsilon_{i t}
\end{aligned}
$$

The theoretical analysis of this paper shows that when the equity structure is under different conditions, the financialization of corporate assets is very likely to be a dynamically changing state for $R \& D$ investment. If only fixed effect regression analysis is used, it may not be able to truly reflect this change. Therefore, it is more reasonable to refer to the panel threshold model proposed by Hansen to explore the direction and extent of asset financialization on R\&D investment under different equity structures. Therefore, in order to verify the above research hypothesis and draw on the panel threshold model proposed by Hansen, this paper proposes the following two measurement models:

$$
\begin{aligned}
& \operatorname{Rd}_{i t}=\alpha_{1} \text { Fin }_{i t}{ }^{*} \mathrm{I}\left(\mathrm{H}_{\mathrm{it}} \leq \gamma\right)+\alpha_{2} \operatorname{Fin}_{i t} * \mathrm{I}\left(\mathrm{H}_{\mathrm{it}}>\gamma\right) \\
& +\alpha_{3} \text { Size }_{i t}+\alpha_{4} \operatorname{Lev}_{i t}+\alpha_{5} Q_{i t}+\alpha_{6} \operatorname{Roa}_{i t}+\alpha_{7} H_{i t} \\
& +\alpha_{8} \text { Manag }_{i t}+\mu_{i}+\varepsilon_{i t}
\end{aligned}
$$

$$
\begin{aligned}
& \operatorname{Rd}_{i t}=\alpha_{1} \text { Fin }_{i t} \text { *I }\left(\text { Manag }_{i t} \leq \gamma\right)+\alpha_{2} \text { Fin }_{i t} \text { *I }\left(\text { Manag }_{i t}>\gamma\right) \\
& +\alpha_{3} \text { Size }_{i t}+\alpha_{4} \text { Lev }_{i t}+\alpha_{5} Q_{i t}+\alpha_{6} \text { Rog }_{i t}+\alpha_{7} H_{i t} \\
& +\alpha_{8} \text { Manag }_{i t}+\mu_{i}+\varepsilon_{i t}
\end{aligned}
$$

\section{The Empirical Results and Analysis}

\subsection{Fixed effect regression analysis}

The regression results show that the multiple regression coefficient of asset financialization (Fin) is 5.879, which is significant at the level of $5 \%$. This result indicates that the financialization of corporate assets has a positive effect on R\&D investment as a whole, which is consistent with the relevant analysis results and supports the contents of Hypothesis 1 .

\subsection{Threshold effect test}

Through the above fixed effect regression analysis, it can be seen that corporate $R \& D$ investment will be affected by corporate asset financialization and its own equity structure Asset financialization will promote R\&D investment. In order to verify whether this relationship between the two will change due to changes in equity structure When a sudden change occurs, this paper selects equity concentration and management shareholding as threshold

\begin{tabular}{|c|c|c|c|}
\hline $\begin{array}{c}\text { Threshold } \\
\text { variable }\end{array}$ & $\begin{array}{c}\text { Threshold } \\
\text { number }\end{array}$ & $\begin{array}{c}\text { Threshold } \\
\text { value }\end{array}$ & $\begin{array}{c}95 \% \text { Confidence } \\
\text { interval }\end{array}$ \\
\hline \multirow{2}{*}{$\mathrm{H}$} & \multirow{2}{*}{$\begin{array}{c}\text { Double } \\
\text { threshold test }\end{array}$} & 22.820 & {$[21.230,22.950]$} \\
\hline & & 25.350 & {$[25.100,27.860]$} \\
\hline \multirow{3}{*}{ Manag } & \multirow{3}{*}{$\begin{array}{c}\text { Triple } \\
\text { threshold test }\end{array}$} & 18.512 & {$[4.464,23.617]$} \\
\hline & & 27.974 & {$[25.553,33.714]$} \\
\hline & & 54.222 & {$[51.961,54.993]$} \\
\hline
\end{tabular}
variables, and uses the model for threshold regression. Firstly, Bootstrap is used to repeatedly extract the data of the main variables of the sample enterprise 1000 times, and the estimated threshold number and corresponding $\mathrm{F}(\mathrm{P})$ value are obtained. The test results of the threshold effect of each variable are shown in Table 1 below.

Table1. Threshold test results

\subsection{Threshold effect analysis}

According to the threshold estimates determined by the above analysis, the corresponding variables are divided into different intervals, and then fixed effect regression estimation (FE) is performed. In order to improve the reliability and persuasiveness of the results and facilitate

\begin{tabular}{|c|c|c|c|c|}
\hline Variable & \multicolumn{2}{|c|}{ Model1 } & \multicolumn{2}{|c|}{ Model2 } \\
\hline $\begin{array}{l}\text { Fin_H1 } \\
(\mathrm{H} \leq \gamma 1)\end{array}$ & $\begin{array}{c}-27.20 * * * \\
5.04)\end{array}$ & $\begin{array}{c}-27.20^{* *}(- \\
2.08)\end{array}$ & & \\
\hline Fin_H2 $(\gamma 1<\mathrm{H} \leq \gamma 2)$ & $21.65^{* * *}(4.23)$ & $21.65^{* *}(2.45)$ & & \\
\hline $\begin{array}{l}\text { Fin_H3 } \\
\left(\mathrm{H}>y_{2}\right)\end{array}$ & $\begin{array}{c}-26.48 * * * \\
4.91)\end{array}$ & $\begin{array}{c}-26.48^{* * *}(- \\
2.91)\end{array}$ & & \\
\hline $\begin{array}{l}\text { Fin_Manag1 } \\
\text { (Manag } \leq \gamma 1)\end{array}$ & & & $\begin{array}{c}-22.91 * * * \\
4.27)\end{array}$ & $\begin{array}{c}-22.91 * * *(- \\
2.66)\end{array}$ \\
\hline $\begin{array}{c}\text { Fin_Manag2 } \\
(\gamma 1<\text { Manag } \leq \gamma 2)\end{array}$ & & & $13.66 * * *(3.13)$ & $\begin{array}{c}13.66^{* * *} \\
(2.00)\end{array}$ \\
\hline $\begin{array}{l}\text { Fin_Manag3 } \\
\left(\gamma_{2}<\text { Manag } \leq \gamma 3\right)\end{array}$ & & & $3.52 * * *(1.06)$ & $\begin{array}{l}3.52^{* * *} \\
(0.24)\end{array}$ \\
\hline $\begin{array}{l}\text { Fin_Manag3 } \\
(\text { Manag }>y 3)\end{array}$ & & & $\begin{array}{c}-17.25 * * *(- \\
3.83)\end{array}$ & $\begin{array}{c}-17.25 * * *(- \\
2.52)\end{array}$ \\
\hline Size & $\begin{array}{c}-0.378 \\
1.46)\end{array}$ & $\begin{array}{c}-0.378 \\
1.38)\end{array}$ & $\begin{array}{c}-0.452^{*}(- \\
1.73)\end{array}$ & $\begin{array}{c}-0.452 \\
1.57)\end{array}(-$ \\
\hline Q & $0.0321(0.66)$ & $\begin{array}{l}0.0321 \\
(0.52)\end{array}$ & $0.0403(0.82)$ & $0.0403(0.70)$ \\
\hline Lev & $\begin{array}{c}-5.125^{* * * *}(- \\
4.65)\end{array}$ & $\begin{array}{c}-5.125^{* * * *}(- \\
3.81)\end{array}$ & $\begin{array}{c}-4.747 * * *(- \\
4.29)\end{array}$ & $\begin{array}{c}-4.747 * * *(- \\
4.29)\end{array}$ \\
\hline Roa & $\begin{array}{c}4.03) \\
-25.43^{* * *}(- \\
10.27)\end{array}$ & $\begin{array}{c}.01 .43^{* * * *}(- \\
6.74)\end{array}$ & $\begin{array}{c}45.96 * * * \\
10.45)\end{array}$ & $\begin{array}{c}45.96 * * * \\
6.92)\end{array}$ \\
\hline _cons & $\begin{array}{l}18.77 \\
(3.20)\end{array}$ & $18.77(3.01)$ & $\begin{array}{l}20.18 \\
(3.43)\end{array}$ & $\begin{array}{l}20.18 \\
(3.06)\end{array}$ \\
\hline $\mathrm{R}^{2}$ & 0.145 & 0.145 & 0.138 & 0.138 \\
\hline $\mathrm{N}$ & 1300 & 1300 & 1300 & 1300 \\
\hline $\mathrm{F}$ & 19.45 & 7.261 & 18.37 & 7.224 \\
\hline
\end{tabular}
comparative analysis, fixed-effect regression estimation (FE_R) of the relevant variables under the robustness standard error was also performed. In Table 2 below, Model 1 and Model 2 represent the empirical results with equity concentration and management shareholding as threshold variables.

Table2. Empirical results of threshold effect

It can be seen from the analysis results that with the change in the concentration of equity, there is a clear nonlinear relationship between asset financialization and enterprise R\&D investment, which confirms Hypothesis 2. When the concentration of equity, that is, the proportion 
of major shareholders holding less than the first threshold of $22.82 \%$, there is a negative correlation between the two, with an impact coefficient of -27.20 , indicating that in the case of diversified equity, companies will invest too much Squeeze out innovative investment. When the concentration of equity is between the first threshold and the second threshold, the dispersion of equity gradually improves. At this time, the impact coefficient is 21.65, from negative to positive, the company holds financial assets and obtains excess returns, which can boost the company's innovation investment. However, when the equity is too concentrated and the second threshold value of $25.35 \%$ is exceeded, this kind of promotion effect will be transformed into an inhibitory effect, and it will become negative again, and the impact coefficient will be reduced to -26.48 . It can be seen that when the concentration of corporate equity is in the range of $[22.82 \%, 25.35 \%]$, the financial assets of enterprises promote the company's R\&D investment.

With the change of management's shareholding ratio, the relationship between the financialization of corporate assets and corporate $R \& D$ investment will also change dynamically, confirming Hypothesis 3. The three thresholds for management holdings divide the impact of asset financialization variables on $\mathrm{R} \& \mathrm{D}$ investment into four ranges. When the management shareholding ratio is less than $18.512 \%$, the impact coefficient is -22.91 at this time, indicating that holding a large amount of financial assets is not conducive to the company's scientific research activities. When the manager's shareholding ratio reaches between the first and second thresholds, the inhibitory effect disappears, the direction of action changes, and there is a positive correlation between the two, with an impact coefficient of 13.66. As the proportion of managers' shareholding further increases and reaches the second threshold of $27.974 \%$, the positive promotion between the two weakened, the impact coefficient was reduced to 3.52. When the percentage of managers' shareholding exceeded the third threshold of $54.222 \%$, the increase in financial investment by companies at this time would have a negative effect on innovation investment, with an impact coefficient of -17.25 . Therefore, it can be seen that when management shares are in the range of $[18.512 \%, 27.974 \%]$, the financialization of corporate assets has the best effect on promoting R\&D investment.

\section{Conclusion and revelation}

This article examines the relationship between the financialization of corporate assets and R\&D investment through collating and empirical analysis of the panel data of 260 listed companies on the GEM during the five-year period 2013-2017, and draws some novel and valuable conclusions. First of all, the financialization of corporate assets has contributed to the overall R\&D investment. Second, the direction and extent of asset financialization on R\&D investment will be affected by the shareholding structure and will change dynamically. With the continuous increase in the proportion of major shareholders, there is a double threshold for the financialization of corporate assets and R\&D investment, that is, "too much." Only when the concentration of equity is moderate can the optimal promotion effect of asset financialization be brought into play. Only in the range of $[22.82 \%, 25.35 \%$ ], the financialization of corporate assets will promote R\&D investment. Under the influence of management's shareholding ratio, there are three thresholds for the financialization of corporate assets and $R \& D$ investment. In the range of $[18.512 \%, 54.222 \%]$, the financialization of corporate assets will only promote $R \& D$ investment. In the range of [18.512\%, 27.974\%], the financialization of corporate assets has the best effect on promoting R\&D investment.

Based on the above research conclusions, the policy suggestion of this article is that, whether it is a government or an enterprise, first of all, it should be fully realized that neither the macro-level real economy development nor the enterprise-level value maximization can be separated from innovation, and the innovation ability greatly depends on the degree of R\&D investment. Secondly, we should make reasonable use of finance to promote its service to the real economy. Therefore, the government should take various effective measures to continue to improve the current financial environment and financial market. For enterprises, they must have a long-term perspective, make strategic adjustments, evaluate and adjust their investment in financial projects, and continuously improve the rationality of financialization. In addition, the full financialization of corporate assets in the process of financialization of corporate assets may be detrimental to corporate investment in R\&D and innovation. Therefore, it is necessary to improve the accuracy of the shareholding structure, properly control the concentration of shareholding and the intensity of management's shareholding, and then give full play to the help function of asset financialization to promote the innovative development of enterprises.

\section{References}

1. Gehringer,A.Growth, Productivity and Capital Accumulation:The Effect of Financial Liberalization in the Case of European Integration[J].International Review of Economics \& Finance,2013,25(C),291309.

2. Zhang Ming,Luo Ling.An Empirical Study on the Impact of Financialization of Private Enterprises on Productivity-Based on the Empirical Analysis of China's A-Share Private Listed Companies[J]. Economic System Reform,2017(05):155-161.

3. Tornell Aaron. Real vs. financial investment can Tobin taxes eliminate the irreversibility distortion?[J]. North-Holland,1990,32(2).

4. Thierry Theurillat,Jose Corpataux,Olivier Crevoisier. Property Sector Financialization: The Case of Swiss Pension Funds (1992-2005)[J]. European Planning Studies, 2010,18(2).

5. Crotty J.The Neoliberal Paradox:The Impact of Destructive Product Market Competition and Impatient Finance on Nonfinancial Corporations in the Neoliberal Era[J]. Research Briefs, 2002, 
35(3):271-279.

6. Peng Yuchao, Han Xun, Li Jianjun. Uncertainty in Economic Policy and Enterprise Financialization[J]. China Industrial Economy, 2018(01):137-153.

7. Song Jun, Lu Yang. U-shaped relationship between non-monetary financial assets and operating rate of return-financialization evidence from my country's listed non-financial companies[J]. Financial Research, 2015(6):111-125

8. Zhong Tianli, Ma Na, Hu Yanbin. Enterprise innovation input factors and financing structure choice-Based on the empirical test of listed companies on the Growth Enterprise Market[J].Accounting Research,2014(04):66-73+96. 